\title{
Murders in Shocking Pink: Women, Love and Desire in Rossana Campo's Noir Fiction
}

\section{Claudia Bernardi}

\begin{abstract}
Summary: This article analyzes Rossana Campo's Mentre la mia bella dorme (1999), Duro come l'amore (2005) and Il posto delle donne (2013) in the context of Campo's work in general, showing how her use of crime genre conventions is specifically designed to reveal flaws and pitfalls inherent in romance narratives. By establishing a complex dialogue between noir and rosa, and by offsetting both traditions with female protagonists who question in different ways the heterosexual paradigm, Campo's crime novels occupy a unique place in her production, especially in regard to the representation of female desire.
\end{abstract}

In their brief but cogent overview of the history of Italian crime fiction, Mirna Cicioni and Nicoletta Di Ciolla highlight a number of characteristics specific to the tradition of the genre in Italy. Firstly, they remind us of its imported origin in French and Anglo-American models. Secondly, they point out how, beginning with the earliest examples produced by feuilleton authors such as Francesco Mastriani, Cletto Arrighi, Emilio De Marchi and Carolina Invernizio in the nineteenth century, Italian crime plots played a role that was secondary to the other genres that dominated the structure and content of their fiction: in those works, "the process of ratiocination and detection were still [...] accessory strands, whilst the focus remained firmly placed on the romantic, adventurous element" (Cicioni and Di Ciolla 1). Thirdly, they accept the notion proposed by many scholars of the genre that while in the first half of the twentieth century Italian readers consumed a lot of translated, "exotic" crime fiction, Italian non-genre writers such as Carlo Emilio Gadda and Leonardo Sciascia incorporated elements of the crime novel in their works, thus "operating a type of genre contamination" and creating "a body of literature which had left behind the standard features of the genre in its classic format, to become protean in appearance as well as visibly sophisticated and innovative in styles and themes" (3).

This portrayal of an imported and hybrid Italian crime novel, with its foreign flavour and its intersections with other popular genres, as well as with 
highbrow literary writing, offers a useful starting point for the exploration of the noir of Rossana Campo (b. 1964). With only three books out of a total of eighteen to date that can be considered to belong to or have affinities with the genre, her crime novels represent only a minimal part of her output. However, the fact that these three novels, Mentre la mia bella dorme (1999), Duro come l'amore (2005) and $I l$ posto delle donne (2013), are also the most dissonant from the heterosexual romance that dominates most of her other fiction singles them out as deserving of special attention. I will discuss them in the context of Campo's work in general, showing how her use of crime genre conventions is specifically designed to reveal flaws and pitfalls inherent in romance narratives. By establishing a complex dialogue between noir and rosa, and by offsetting both traditions with female protagonists who question in different ways the heterosexual paradigm, Campo's crime novels occupy a unique place in her production, especially in regard to the representation of female desire.

A very prolific writer, as well as an artist and illustrator of many of her own book covers, ${ }^{1}$ Campo has maintained a faithful readership and critical attention since she started publishing in 1992. Besides her twelve novels for adult readers, Campo has authored two children's books (La gemella buona e la gemella cattiva, 2000; Piccoli budda, 2013), one radio play (Il matrimonio di Maria, 1998), a memoir of her father (Dove lo trovate un padre come il mio, 2015) and a book based on her twenty years of Buddhist practice (Felice per quello che sei. Confessioni di una buddista emotiva, 2013). Her writing career started under the patronage of the neoavanguardia intellectuals, whom she has openly acknowledged as her literary models (Litherland 128). Several scholars, such as Silvia Contarini, Nicoletta Di Ciolla McGowan, Stefania Lucamante (Italian Pulp Fiction) and Massimo Arcangeli, have highlighted the debt her early fiction owes to the Gruppo 63, from Edoardo Sanguineti, with whom she studied at the University of Genoa, ${ }^{2}$ to Gianni Celati, who included an excerpt from her fiction in his anthology of new writers, Narratori delle riserve (1992). Celati himself suggested a link between Campo and Sanguineti, noting a comparable interest in using colloquial registers and vocabulary (66).

Campo's own take on her relationship with the neoavanguardia is represented meta-narratively through the love/hate relationship between her first-person

\footnotetext{
${ }^{1}$ A selection of her art can be found in L'arte soppianta tutti gli enzimi (2012).

${ }^{2}$ She graduated with a thesis on Luigi Malerba.
} 
female narrators and their male love interests, who are often older intellectuals. Nowhere is this more apparent than in the love story between the narrator and the "pittore futurista" of In principio erano le mutande (1992), her first novel. The man's artistic credentials are a source of admiration but also of amusement for the narrator, who acknowledges him as a potential soulmate only after he confesses his love for Emily Brönte's Wuthering Heights. In my view, this expresses Campo's attempt to reconcile her two main literary models: the predominantly male, highbrow experimental tradition represented by the avant-garde artist, and the tradition of women's romance symbolized by Emily Brönte's novel. The happy ending of the novel is determined more by an act of narrative desire than by consistent character or plot development, a humorous merging of its multiple literary models: the popular, low-brow tradition of the love plot and the high-brow experimentalism of the neoavanguardia. ${ }^{3}$

Since her early works, however, Campo has become less preoccupied with proving her experimental credentials and more interested in integrating popular genres into her narrative. Her attitude towards genre writing comes across as both serious and ludic:

La letteratura di genere è un qualcosa che m'interessa. Secondo me è importante che uno scrittore faccia i conti con la letteratura di genere. È importante non lasciare ai lettori solo libri di serie B perché sono capaci di raccontare una storia. $\mathrm{E}$ in effetti, mi sono cimentata con il genere poliziesco, con quello rosa-sentimentale, la letteratura memorialistica, famigliare, eccetera, sempre stravolgendoli, ovviamente, sempre facendo delle incursioni e prendendone le distanze. (qtd. in Litherland 133)

In this statement, Campo betrays an ambiguous stance whereby she justifies her use of genres "perché sono capaci di raccontare una storia" while at the same time distancing herself from the "libri di serie B" that she believes dominate genre writing. This position echoes how critics have historically viewed the incursions

\footnotetext{
${ }^{3}$ Intriguingly, the film adaptation of the novel significantly alters the nature of the relationship between the protagonist and the "pittore futurista," transforming him into a minor, annoying character. The protagonist of the movie instead falls in love with a fireman, who in turn plays a very minor role in the novel. The film was directed by Anna Negri and was released in 2000. The screenplay is credited to Rossana Campo, Ivan Cotroneo, Davide Ferrario, Doriana Leondeff and Anna Negri, and it seems to anticipate Campo's later protagonists' dislike for self-important male intellectuals.
} 
into giallo and noir made by many well-regarded non-genre authors, from Gadda to Eco, from Tabucchi to Maraini. Recent studies of Italian crime fiction have emphasized the use of its tropes and conventions by non-genre writers, who are attracted by the flexibility of a genre that can both voice contemporary sociohistorical anxieties and offer postmodern writers the ideal platform for their meta-narrative preoccupations. ${ }^{4}$ Barbara Pezzotti contends, however, that an outdated prejudice remains on the part of scholars who applaud the appropriation of giallo conventions by non-genre authors, and by doing so implicitly devalue those writers who fully embrace the genre. "It can be otherwise argued," Pezzotti goes on to say, "that instead of appropriating (and ennobling) the crime fiction formula, twentieth century Italian 'highbrow' literature has been revitalized and transformed by crime fiction tropes and themes" (4).

Despite her statements on the matter, Campo's works show that she fully recognizes the vitality of genre fiction, and throughout her career she has constantly engaged with the tradition of heterosexual romance. Campo has explored and continues to explore the formal and linguistic possibilities of telling love stories about women, and by intersecting these stories with other genres, such as crime fiction, she has tested the limits and flexibility of both and their ability to produce meaningful narratives. ${ }^{5}$ Her early novels portray young women's quests for love, passion and sexual fulfilment in optimistic terms, complete with improbable happy endings of the type exemplified by In principio erano le mutande. But her later fiction and older protagonists take a more complex approach, one that highlights the pitfalls of romantic love while refusing to condemn the persistent attractiveness of its myth among women. Even in her darkest, most dramatic books, Campo remains steadfast in her use of tropes, intertextual references, storytelling modes and characterization that belong to the rich and varied tradition of

\footnotetext{
${ }^{4}$ See, among others, Cannon; R. Wilson; Farrell; and Pieri.

${ }^{5}$ Equally important is the intertextual presence of cinema in her narrative. The exchange between the two media is especially apparent in L'attore americano (1997), where the improbable love story between the protagonist and a Mickey Rourke-modelled movie star echoes the plot of Woody Allen's The Purple Rose of Cairo (1985), as proposed by Lucamante ("Per uno sguardo diverso"); see also Viazmensky. Campo's dialogue with films is also evident in her radio play Il matrimonio di Maria (1998), a retelling of Ang Lee's gay-themed, American-Chinese family drama The Wedding Banquet (1993) as a lesbian-themed, NorthSouth Italian family farce.
} 
women's romance, as evidenced in the many words and expressions associated with romantic love that appear in her titles. ${ }^{6}$

However, the pursuit of love and sexual fulfilment that drives Campo's heroines is never presented acritically. In her early fiction this critical stance is articulated by the chorus of female voices that constantly comment on the narrators' adventures. In Mai sentita cosi bene (1995), this female chorus exclusively occupies the diegetic space of the narrative, relegating the presence of the male love interests to the contents of the women's conversations. ${ }^{7}$ While the tone of the first three novels is lighthearted and optimistic about the possibility of achieving happiness through love, Campo's later fiction introduces increasingly pessimistic notes. This is especially evident in the gradual shift of the character of the older male intellectual towards a darker, problematic, at times even menacing presence in the protagonists' lives: this shift highlights Campo's increasing questioning of the heterosexual romance narrative, but the three titles that stand out as critiques of the heterosexual love plot are, as already mentioned, Mentre la mia bella dorme, Duro come l'amore and Il posto delle donne. In these novels, the first-person female protagonists find themselves targeted as possible victims or involved in the investigation of murders of other women. Chronologically, Mentre la mia bella dorme, from 1999, precedes Duro come l'amore, which was published in 2005. However, I will discuss Duro come l'amore first for two reasons: unlike what happens in Mentre la mia bella dorme and in Il posto delle donne, where the main characters conduct amateur investigations to solve murders that are central to the plots, in Duro come l'amore the serial killer subplot remains secondary throughout; in fact, the reader eventually finds out that the connection between subplot and main story exists only in the narrator's perception, fuelled by her own sentimental anxieties. As well as being the most overt examples of noir written by Campo, Mentre la mia

\footnotetext{
${ }^{6}$ The term "amore" explicitly appears in two titles, Duro come l'amore (2005) and Fare l'amore (2014), while others include references to marriage (Il matrimonio di Maria, 1998; and L'uomo che non ho sposato, 2003), to amour fou and irrepressible sexual passion (Sono pazza di te, 2001; and Più forte di me, 2007), and to sexual intercourse (even though jokingly) In principio erano le mutande (1992) and Il pieno di super (1993).

7 The exclusively female conversations that populate Campo's novels are a direct reference to the feminist practice of collective discussion and consciousness-raising developed in Italy during the 1970s and 1980s (Di Ciolla McGowan 171, 174; Bernardi 79-80). I agree with Valerio Ferme when he argues that "the awareness of feminist discourse and theory shows that beneath the apparent superficiality of the women's banter there exists a clear political agenda and manifesto, one that is intimately tied with the narrative and linguistic form" (147).
} 
bella dorme and Il posto delle donne are also her novels that most explicitly present sexual and romantic desire between women: for this reason, the two books should be discussed one after the other. I will in fact propose that the similarities between the two novels and the deliberate callbacks from the later book to the ealier one authorize a reading of $\mathrm{Il}$ posto delle donne, published in 2013, as the fully lesbian narrative that Mentre la mia bella dorme had failed to be fourteen years earlier.

All three novels align themselves with noir rather than giallo in so far that they, like the novels of the noir tradition, "do not trust in the investigation as a clearly defined process which moves towards the re-establishment of order, but aim instead at revealing the chaos that lies behind human existence" (Di Ciolla 11). The accidental detectives of Mentre la mia bella dorme and Il posto delle donne present characteristics typical of the hard-boiled investigator who recklessly pursues an elusive truth in an increasingly hostile environment, following her own intuition and gut instinct rather than superior deductive reasoning: "niente colpi di genio e osservazioni acute, piuttosto una buona conoscenza della natura umana e dei suoi vizi" (Cappi 55). Paris, the romantic city par excellence, reveals its darker side, comparable to the "shabby and depressing reality beneath its painted façade" that the detectives of the American hard-boiled tradition would uncover in Los Angeles and Hollywood (Grella 112). The tradition itself is one that has evolved significantly since its beginnings in the 1920s, and Lewis D. Moore proposes a division between three main periods, Early (1927-1955), Transitional (19641977) and Modern (1979-present), each with its own characteristics. The profound social changes of the 1970s and 1980s spurred the development of modern hard-boiled narratives with the introduction of many diverse characters, including female and homosexual sleuths. These characters have forced the genre to address themes of gender and sexuality, which have often become an integral part of the crime plots: "The character of the detective dominates the genre. The many plots are, as it were, drawn into the character of the detective" (Moore 278). Maureen Reddy argues that feminist crime novels have thrived to the extent that they have provided the genre with a counter-tradition, the main characteristics of which are "the violation of linear progress, the ultimate absence of authority as conventionally defined, and the use of a dialogic form" (Reddy 2). At the level of content, the authors of these books often identify the origin of the violence and death in their plots in the patriarchal social and cultural structure inhabited by their characters. Some of these formal and thematic elements also appear in Campo's novels, as I discuss below, but it is perhaps premature to talk of a feminist counter-tradition 
of the genre in Italy. Nevertheless, recent crime novels written by women such as Barbara Garlaschelli and Fiorella Cagnoni also "articulate anxieties and challenges faced by women of today, including the right to assert a transgressive sexuality" (Di Ciolla 111). With their attention for women and for the way men perpetrate violence upon them, Campo's forays into the genre can in all respects be considered representative of feminist crime fiction, especially due to their "focus on marginal and marginalized characters," which Giuliana Pieri and Lucia Rinaldi see as a defining feature of the "profound engagement" Italian women crime writers have with current social and political issues (Pieri and Rinaldi 124).

While in several of her other novels Campo combines love storylines with elements of other genres, in Duro come l'amore the background mystery plot becomes an effective device for upsetting romance expectations. By regularly reminding them of the serial killer that is roaming the streets of Paris, Campo alerts her readers to the danger that might lurk beneath the protagonist's adulterous passion for an older man. Against the backdrop of a late Parisian winter, the Italian expatriate embarks upon an affair with Felix, a failed artist and photographer with a history of mental illness who nostalgically remembers the 1960s and 1970s (in particular his experiences in Trieste with psychiatry reformer Franco Basaglia) and who has a morbid attachment to the memory of his mother. From their first meeting in a supermarket, she thinks "è lui il killer pazzo" (14). For the first-person narrator, this relationship plays out as an escape from the emotional desert her marriage has become. Serge, her husband, is a psychiatrist who, from the height of his intellectual superiority, provides a profile of the serial killer who has been murdering single women in the fifth arrondissement:

Quello che si riscontra nel passato di queste persone è spesso una storia di litigi, violenze e mancanza d'amore da parte dei genitori. Poi sempre centrale il rapporto col padre, in quasi tutti gli assassini psicotici c'è una grossa assenza e dei traumi legati alla figura paterna. (151)

Inizia delle relazioni, fa l'amore qualche volta, finché comincia a diventare più violento, per lui il desiderio sessuale è legato alla rabbia, ha aggressività nelle sue fantasie e nel suo modo di scopare. Poi l'aggressività aumenta, fino ad arrivare all'omicidio.

[...] 
Secondo me è un ossessivo, uno che ha un comportamento di tipo ossessivo, con fobie, tic, rituali, scatti violenti di collera... (153)

As the story progresses, the protagonist become increasingly aware that her lover, Felix, matches the profile of the serial killer: he follows her and her husband's lives in a stalkerish manner, displays sudden outbursts of violence, expresses his desire to be rid of his own wife and relatives, takes the narrator to his late mother's home and makes love to her on his mother's bed. She chooses to pursue a relationship with him in spite of her fears, or perhaps because of them: "quest'uomo mi spia, forse conosce le mie abitudini. Forse ho paura di lui e non mi è facile ammetterlo. Forse mi eccita e anche questo non mi è facile ammetterlo" (45). She confesses to her friends that she likes his fragility, but also that she is afraid of his latent violence, and when he becomes more overtly possessive and aggressive, she tells herself "che se Felix è un assassino a questo punto era troppo tardi, a questo punto non potevo più tirarmi indietro" (178). The affair gradually unravels and reaches a breaking point on a final car trip to Fontainbleau: during a violent fight, Felix hits her on the head with a wrench. Terrified, she manages to escape, but, ultimately, the serial killer is revealed to be someone else altogether, a stranger who, ironically, only partially matches the profile so confidently drawn by Serge. Her increased awareness that both her husband and her lover display patterns of behaviour not entirely dissimilar to those of a murderer leads the protagonist to leave both, and ultimately to question her own dreams of fulfilment through heterosexual romance. The final pages show her seeking solace in friendship, in the company of old and new friends who have offered her support and advice throughout her doomed affair.

Although Duro come l'amore lies outside the crime genre proper, as the threat of the real serial killer remains separate from the threat posed by the protagonist's lover and the incomprehension of her husband, the safety provided by a mainly female community is a trope of Anglo-American feminist crime fiction in general and of lesbian crime fiction in particular (Irons xiii-xiv; Klein 178). In Mentre la mia bella dorme and Il posto delle donne, however, these tropes come under scrutiny, and Campo's readers are forced to ask themselves whether a safe community is viable at all. These books are by no means the first instances in which Campo introduces lesbian or bisexual women into her fiction. As noted earlier, the radio play Il matrimonio di Maria is centred around a lesbian couple who agrees to the fake heterosexual marriage of one of them to appease her family, while minor 
lesbian or bisexual characters appear in several other novels. ${ }^{8}$ In the case of Mentre la mia bella dorme and Il posto delle donne, however, lesbians take centre stage as fully developed characters, and women's same-sex desire is a main narrative drive, triggering the protagonists' investigations. While lesbian subtexts and eventually main plots have appeared before in Italian giallo in the novels of Fiorella Cagnoni, ${ }^{9}$ they have done so cautiously and elusively, as noted by Mirna Cicioni: "Significant evidence of this is the total absence of description of any kind of physical intimacy between any of the characters" (153). By contrast, the physical intimacies between the female characters of Mentre la mia bella dorme and Il posto delle donne are described in detail. In this sense, Campo's novels are aligned with the well-established Anglo-American tradition of lesbian sleuth fiction, where sex and romance are far more prominent than in the straight hard-boiled tradition (Simpson 11-12). ${ }^{10}$ Romance and coming-out plots, with their important corollary of sexual awakening, are in fact so central to the lesbian crime tradition that the mysteries are often shifted "to the wings" (Reddy 16). ${ }^{11}$ And love and sexual desire play a very important role in Campo's novels, although the crimes and the protagonists' search for truth remain central to both books.

In Mentre la mia bella dorme, the limits of heterosexual romance are signalled right away by the fact that the protagonist/narrator, again an Italian expatriate and crime reporter for Dépêche de Paris, is seven months pregnant and has been abandoned by the father of her child. The heat of the sweltering Parisian summer is no match for her rage towards the man, and she meanders through the streets of the city in search of distraction, against the advice of her doctor, who recommends

\footnotetext{
${ }^{8}$ Lella, "la gastroenterologa" of In principio erano le mutande, with whom the protagonist has a brief relationship before meeting her "pittore futurista"; Valeria, the one lesbian character to appear in the exclusively female but otherwise entirely heterosexual cast of Mai sentita cosi bene; "la poliziotta bretone" dated concomitantly with male lovers by one of the protagonist's friends in Duro come l'amore.

${ }^{9}$ But note also the lesbian policewoman in Dacia Maraini's Voci (1994).

${ }^{10}$ Simpson claims that this departure from the straight detective canon also applies to the majority of gay detective fiction. In contrast with what I see as a fruitful contamination between genres in the Italian context, Simpson argues that the overwhelming presence of romance (and sex) is preventing Anglophone lesbian detective fiction from becoming more mainstream: "lesbian detective fiction remains stalled-torn between genres, no longer a radical outsider or engaging a broader readership” (18).

${ }^{11}$ Anna Wilson (1996) argues, however, that the popularity of lesbian detective fiction displaced the coming-out novel among American readers.
} 
calm and relaxation: "voglio sentirmi tesa e con la voglia di spaccargli la faccia al bastardo" (9). After an evening in the company of her friend Pauline turns a little too boisterous, she receives a visit from their neighbour, the emerging musician Fruit/Marianne. The protagonist is immediately smitten with Fruit and the sense of hope that radiates from her:

Emana qualcosa di selvatico questa Fruit. Come una forza, una specie di fiducia nel futuro. La maggior parte delle persone crescendo la perde questa corrente incontaminata. Accettano di essere piallati, comprano case, mettono su famiglie assurde e prendono pillole contro la depressione, la pressione alta e il colesterolo. Fruit mi dà l'idea di una cosa che non finirà così, di una che non permetterà alla vita di distruggerla. E questa cosa mi fa sentire bene e mi dà anche un po' di voglia di proteggerla. (21)

An unplanned night together, the first lesbian experience for the protagonist, offers the promise of a new romance between the narrator and the young musician. Although this is a new experience for the narrator, she never problematizes same-sex female desire, nor her continued heterosexual interests, and the novel never turns into a coming-out story. The narrator's reaction to what she expects to be a one-night stand is to retreat into self-protective mode and tell herself not to hope for more. Despite her defensive stance, her elation at the possibility of a new relationship is tangible, and her optimism is rewarded by a call from Fruit that defies all codified rules of heterosexual courtship: "sono contenta che qualcuno con cui ho passato la notte si faccia vivo, alle quattro meno un quarto del pomeriggio dopo. E che cazzo" (29). Instead of brushing her off, as the narrator has learned to expect of her heterosexual partners, Fruit invites her to go on tour to the Lilith Fair Festival. This elation, however, is cut short by Fruit's sudden death, an apparent suicide. Other possible romances, such as the one with Krasicki, the male police officer in charge of the case, eventually fizzle out because the protagonist cannot accept the suicide verdict on Fruit's death. She cannot reconcile the fact that her new lover could have committed suicide just as she had enthusiastically invited her to travel together. Following a well-established crime fiction trope, the investigative reporter embarks upon a private investigation of her own. She conducts her search through the hottest Parisian summer (with a detour to London), guided by her own instinct, "una specie di filo d'acciaio, teso dalla pancia al cervello, giusto per fare un paragone" (43). After unravelling a web of decade-long lies that 
involve Marianne's bourgeois mother (in reality grandmother) Madame Irene de Rivelange, as well as her aunt Janine (in reality Fruit's natural mother), the narrator eventually identifies the murderer in Marianne's natural father, an ex-sessantottino who had experienced free love in a commune during the 1970s and had fathered Fruit by raping the fourteen-year-old Janine. He is now a wealthy and respected member of the French establishment: he has murdered his own daughter to avoid a public scandal. During the course of the investigation, the narrator comes face to face not only with Fruit's official and natural mothers, but also with many other figures: her lover and agent, the aloof Catherine Kahn; Fruit's official father, the transvestite Nick Durrell/Kristy Hand; and Fruit's best friend, Frank Tourè. All of them reveal, to various degrees, their fundamental indifference towards Fruit's life, and therefore an underlying disinterest in the circumstances of her death, whether in order to preserve their social status or simply for a lack of courage or interest in pursuing the truth. When the truth is finally revealed, a melodramatic act of revenge at the hands of Fruit's natural mother fails to restore a real sense of justice. This pessimism is compounded by the fact that, like in many other works by Italian women writers of crime fiction, the traditional family, focused on the preservation of its veneer of patriarchal, heteronormative respectability, is revealed "as a locus of crimes" (Di Ciolla 109). ${ }^{12}$ The only hope left in Mentre la mia bella dorme lies in the promise of a different relationship that the narrator will establish with the daughter she is about to bring into the world, and in her ability to at least provide her with a new type of family. ${ }^{13}$

Il posto delle donne, written almost fifteen years after Mentre la mia bella dorme, reads in many ways like a rewriting of that earlier book, now fully committed to a narrative of desire between women. While the mainly heterosexual protagonist of Mentre la mia bella dorme had almost accidentally fallen into a relationship with Marianne, the narrator of Il posto delle donne, Emma, identifies as a lesbian. Nevertheless, the detection that unfolds reveals how the limits of heterosexual romance conventions are comparable to those of the romantic and

\footnotetext{
${ }^{12}$ For a discussion of the family as a staple place of "lies and deceit" in American and British hard-boiled fiction, see Moore (258-279).

${ }^{13}$ On the new family models, "chaotic, non-hierarchical but emotionally rich [...], often devoid of a male (or heterosexual male) presence," evident in crime novels by Italian women, see Pieri and Rinaldi (125). The notion of a "chosen family" that supersedes the traditional heterosexual family in the female detective's life regardless of her sexuality arches back to the British and American feminist crime fiction of the 1980s (Reddy 109-111).
} 
sexual lesbian relationships that Emma must navigate in order to catch Maxine's murderer. Exactly like in the previous novel, the story opens with the narrator falling apart after she has been abandoned by her former lover, Carmen, and fighting against her own simmering violence: "Forse, ti dovrei uccidere, dovrei avere il coraggio di farlo" (9), she silently addresses Carmen in her head. Like the protagonist of Mentre la mia bella dorme, she externalizes this dramatic change in her life by purchasing a new leather jacket and getting a new haircut, "[un] taglio radicale" (14). Similarly to the reporter of the previous novel, she has a stalker who harasses her with obscene phone calls, and following the same narrative pattern, Emma-who works as a waitress in a gay cafe-bookshop—has what seems to be a one-night stand with a young woman, Maxine, whom she nicknames Punketta. Once again the narrator harbours a faint hope that the encounter might develop into something more: "Mi sono messa a pensare come potrebbe essere la vita con Punketta, come sarebbe stare con una ragazza che fa lo striptease a Pigalle" (41); but before any romance has the chance to blossom, Maxine is murdered. As in the case of Fruit, the police are not truly invested in this case because, as an exotic dancer, Maxine is categorized as a prostitute and therefore her death is considered an occupational hazard, a consequence of her walking alone at night. Emma, however, cannot forget the young woman's openness to life, however briefly she experienced it:

Fra tutte le persone incontrate in questi ultimi tempi Punketta mi era sembrata la migliore, la più reale. Perché negli incontri lei ci credeva ancora e le piaceva un mondo fare cazzate, truccarsi troppo, parlare della saggia Catherine e rimorchiare le donne.

Avevo provato a immaginare che fosse ancora viva, a Pigalle, che stesse ballando da Victor, e mentre ballava forse pensava anche alla nostra notte insieme. Lei aveva trovato qualcosa di buono perfino in quel posto dove lavorava, magari trovava anche passabili i turisti che andavano a guardarla, e il barista stronzo. Sono sicura che trovava qualcosa di buono in ogni situazione. Perché l'aveva trovato anche in me. (47-48)

Following the faint trail of clues Maxine has left behind, Emma begins an investigation that will lead her not so much to catch the killer as to reconstruct how disposable the young woman was in the lives of those she had encountered, how vulnerable she was to the many levels of violence that surrounded her. Emma's 
own vulnerability during the investigative process marks her as an outsider. As Mirna Cicioni reminds us, the position of the lesbian investigator in the crime fiction canon is a very precarious one:

[I]t can be safely stated that the lesbian sleuth, whether she is part of a police department, a private investigator or a freelance amateur, is an outsider. She is triply marginalized: by her sex, by her choice to encroach upon male territory, and by her sexuality, which is either an explicit given, or the explicit conclusion of a process of self-discovery. (145)

In Emma's case, the self-discovery consists in finding out that one can be an outsider also within a community of women who love women. This becomes apparent when she meets the young woman's older lover, Catherine Forest, a feminist philosophy professor who looks like "una signora borghese come tante, una prof elegante, intellettuale, con la pelle chiara e i capelli biondi con le mèches" (51). Catherine and her long-term partner, Alicia, have established a relationship based on unspoken rules and allowances for extra-curricular liaisons that are as impenetrable and exclusive as the strictest monogamy, and Emma herself has a brief, unsatisfactory affair with Catherine. While neither Catherine nor Alicia has killed Maxine, they cannot hide their relief that, thanks to her death, her youth, exuberance and lust for life cannot cause any further disturbance to their well-established relationship patterns, their respectable intellectual careers, their expensive haircuts. The type of passion Maxine had brought into their lives exceeded the levels they deemed acceptable: "Maxine non sapeva stare al suo posto. Non sapeva cosa significa rispettare le precedenze" (106), explains Alicia. As a playwright and theatre director, Alicia bullies her actresses to perform their passions and desires without reticence, but ultimately those emotions must be left on stage; and while Catherine rages violently against Emma once she discovers her brief affair with Alicia, she also concludes that "la gelosia è un sentimento ignobile" (92).

Violent passions simmer in the world of women that Emma uncovers through her investigation, while also witnessing her own ex-girlfriend's extreme hostility in a public scene where she demands the immediate return of a sweater Emma is wearing (a very similar scene between the narrator and her male ex-lover also appears in Mentre la mia bella dorme). But ultimately none of these women have murdered Maxine, in the same way that Emma can never really bring herself to kill Carmen or Carmen's new lover despite her desire to hurt them. Once again, 
the real violence is perpetrated by men on women. In the course of her unofficial investigation, Emma is viciously and gratuitously beaten up by Henry, the barman of Chez Victor who has a history of forcing the women who work at the club into prostitution. Despite her bravado, Emma experiences the full impact of men's violence and of her own vulnerability as a woman:

Io sono inebetita, non ho la forza di reagire, non riesco nemmeno a muovere le labbra. Mi sono scontrata con le possibilità limitate del mio corpo, avrei voluto essere più forte, avere una maggiore forza nei muscoli, essere abituata a lottare, a prendere cazzotti e a restituirli. Ho sentito per la prima volta in modo così duro cosa significa avere un corpo di donna, una vita di donna. (128)

As the trail of Maxine's murder goes gradually cold, Emma begins to wonder if her murderer will ever be brought to justice. By chance she discovers the identity of her own phone stalker and, armed with a gun, decides to confront him; at the crucial moment, however, she does not shoot, unable to bring herself to kill another human being. Like in Duro come l'amore, the real murderer turns out to be someone entirely unrelated to Emma's investigation: a stranger, a man who took his marital frustrations out on Maxine, "uno che passava da quelle parti per caso" (149). The denouement is deliberately anti-climatic, to underline the distinction between the real motivations behind Emma's investigation, the outcome of her search, and abstract concepts of justice. While the investigation does not bring Maxine's murderer to justice, it turns into a journey of self-discovery for Emma, who finally accepts the breakup from her former lover. Unlike the women and men who had desired Maxine but who-similarly to Fruit's family in Mentre la mia bella dorme- had also kept her at the margins of their lives or who had used her as an object of their frustrated sexual desires, Emma chooses to welcome the uncontrollable chaos of a new and pregnant lover, Christelle: the mess of life in all its emotional complexity, which Maxine had heralded. In the darkest moment of her pursuit, Emma had asked herself: "Qual era la cosa giusta che bisognava fare per stare bene al mondo, usare la violenza oppure insistere ad amare?" (137). Ultimately, the only real answer to her investigation is the choice she makes to continue to love, represented narratively by an open but hopeful ending, a blossoming romance between women, while the noir is pushed to the side and resolved almost as an afterthought. 
Identifying some common elements of Italian crime novels by women, $\mathrm{Di}$ Ciolla highlights not only the presence of themes and contents that are of particular concern to them, but also the prevalence of narrative strategies such as dialogic voices that allow for "the expression of diversity" and "the discarding of the statutory process of closure and restoration of order as the guaranteed outcome" in favour of open endings (73). These characteristics are all present in Campo's noir novels: while protagonists and investigators coincide in the voices of first-person narrators, their perspectives are constantly checked against their ongoing dialogues with other characters, most of whom are also expatriates, non-conformist, marginal, "eccessiv[i] e inopportun[i]" (Mentre la mia bella dorme 23). And while the endings reveal the culprits of the murders, they also leave many issues unresolved: will Felix eventually give in to his most violent instincts and resort to murder, fulfilling his serial-killer profile? Will Henry, the barman and pimp of Chez Victor, ever be brought to justice for his violence against Emma and other dancers at the club? Will the characters who have been complicit in Fruit's death through their indifference ever experience remorse? These questions are deliberately left unanswered. George Grella tells us that "[ $\mathrm{t}]$ he detective of the hard-boiled novel generally solves his mystery in a hurried, disordered fashion, in the last few pages of his book, with little effort to clear up all the points or tie up all loose threads" (115); Campo's novels stay true to that tradition.

To conclude, Campo's use of genre conventions and intertextual echoes and her constant reinvention of recurring themes and characters serve as a foil to the dominant presence of romance and as a reminder that the limits of any genre can be simultaneously challenged and stretched. This is particularly important in matters of the representation of women's sexuality and desire in Italian fiction. In the three novels I have discussed here, young women are murdered or threatened for their real or perceived challenges to conventional female sexuality: the single women of Duro come l'amore are punished by a serial killer for inviting him into their houses and seeking sexual fulfillment; in Mentre la mia bella dorme, Fruit/ Marianne is silenced by her natural father for wanting to know and perhaps reveal the truth about his rape of her natural mother; and in $\mathrm{Il}$ posto delle donne, Maxine is murdered for being in a sexualized profession, presenting herself as a fully sexual being and yet daring to turn down a stranger with his own grudge against women. These murders have the function of maintaining a patriarchal and heteronormative sexual and social order. The accidental investigations undertaken by other women (who desire women), by Italian expatriates in Paris whose lives 
are equally messy and chaotic, do not always vindicate the victims of these crimes, but they at least restore the disorder the victims had embodied with their free and passionate lives.

Victoria University of Wellington, $N Z$

\section{Works Cited}

Arcangeli, Massimo. Giovani scrittori, scritture giovani. Ribelli, sognatori, cannibali, bad girls. Rome: Carocci, 2007.

Bernardi, Claudia. "Recalcitrant Daughters: The Search for Literary Mothers in Italian Women's Fiction of the 1990s." In Women's Writing in Western Europe: Gender, Generation and Legacy. Ed. Adalgisa Giorgio and Julia Waters. Newcastle: Cambridge Scholars Publishing, 2007. 69-84.

Campo, Rossana. L'arte soppianta tutti gli enzimi. Genoa: Il Canneto, 2012. . Dove lo trovate un padre come il mio. Florence: Ponte alle Grazie, 2015. . Duro come l'amore. Milan: Feltrinelli, 2005. . Fare l'amore. Florence: Ponte alle Grazie, 2014. . Felice per quello che sei. Confessioni di una buddista emotiva. Rome: Giulio Perrone Editore, 2012. - La gemella buona e la gemella cattiva. Milan: Feltrinelli, 2000. . In principio erano le mutande. Milan: Feltrinelli, 1992. . Mai sentita così bene. Milan: Feltrinelli, 1995. . Il matrimonio di Maria. Milan: Feltrinelli, 1998. . Mentre la mia bella dorme. Milan: Feltrinelli, 1999. - Piccoli budda. Rome: Gallucci, 2013. . Il pieno di super. Milan: Feltrinelli, 1993. . Più forte di me. Milan: Feltrinelli, 2007. . Il posto delle donne. Florence: Ponte alle Grazie, 2013. . Sono pazza di te. Milan: Feltrinelli, 2001. . L'uomo che non ho sposato. Milan: Feltrinelli, 2003.

Cannon, JoAnn. The Novel as Investigation: Leonardo Sciascia, Dacia Maraini, Antonio Tabucchi. Toronto: U of Toronto P, 2006. 
Cappi, Andrea Carlo. Elementi di tenebra. Manuale di scrittura thriller. Milan: Alacrán edizioni, 2005.

Celati, Gianni, ed. Narratori delle riserve. Milan: Feltrinelli, 1992.

Cicioni, Mirna. "Loyalties and Lesbianism in the Novels of Fiorella Cagnoni." In Differences, Deceits and Desires: Murder and Mayhem in Italian Crime Fiction. Ed. Mirna Cicioni and Nicoletta Di Ciolla. Newark: U of Delaware P, 2008. 145-159.

Cicioni, Mirna, and Nicoletta Di Ciolla. "Introduction." In Differences, Deceits and Desires: Murder and Mayhem in Italian Crime Fiction. Ed. Mirna Cicioni and Nicoletta Di Ciolla. Newark: U of Delaware P, 2008. 1-8.

Contarini, Silvia. "L'eredità della Neoavanguardia nei romanzi di Silvia Ballestra, Rossana Campo, Carmen Covito." Narrativa 8 (1995): 77-99.

Di Ciolla, Nicoletta. Uncertain Justice: Crimes and Retribution in Contemporary Italian Crime Fiction. Newcastle: Cambridge Scholars Publishing, 2010.

Di Ciolla McGowan, Nicoletta. "Giovani pulp crescono. Il percorso della narrativa italiana degli anni Novanta nell'opera di Rossana Campo." Narrativa 14 (1999): 167-181.

Farrell, Joseph. "Literature and the Giallo: Gadda, Eco, Tabucchi e Sciascia." In Italian Crime Fiction. Ed. Giuliana Pieri. Cardiff: U of Wales P, 2011. 48-72.

Ferme, Valerio. "Gay, Feminist, and Arberesh: Marginal Italian Identities in the Fiction of Aldo Busi, Rossana Campo, and Carmine Abate." Annali d'italianistica 24 (2006): 133-158.

Grella, George. "The Hard-Boiled Detective Novel." In Detective Fiction: A Collection of Critical Essays. Ed. Robin W. Winks. Englewood Cliffs, NJ: Prentice-Hall, 1980. 103-112.

Irons, Glenwood. "Introduction: Gender and Genre: the Woman Detective and the Diffusion of Generic Voices." In Feminism in Women's Detective Fiction. Ed. Glenwood Irons. Toronto, Buffalo, London: U of Toronto P, 1995. ix-xxiv.

Klein, Kathleen Gregory. "Habeas Corpus: Feminism and Detective Fiction." In Feminism in Women's Detective Fiction. Ed. Glenwood Irons. Toronto, Buffalo, London: U of Toronto P, 1995. 171-189.

Litherland, Kate. "Rossana Campo: Unlearning the Rules of Writing." The Italianist 24 (2004): 126-134. 
Lucamante, Stefania, ed. Italian Pulp Fiction: The New Narrative of the Giovani Cannibali Writers. Madison, Teaneck: Fairleigh Dickinson UP, 2001. . "Per uno sguardo diverso: Cinema, Santa Cecilia e Mickey Rourke nell'Attore americano." Narrativa 20-21 (2001): 19-34.

Maraini, Dacia. Voci. Milan: Rizzoli, 1994.

Moore, Lewis D. Cracking the Hard-Boiled Detective: A Critical History from the 1920s to the Present. Jefferson, NC and London: McFarland, 2006.

Pezzotti, Barbara. Politics and Society in Italian Crime Fiction: An Historical Overview. Jefferson, NC: McFarland, 2014.

Pieri, Giuliana. "Introduction." In Italian Crime Fiction. Ed. Giuliana Pieri. Cardiff: U of Wales P, 2011. 1-5.

Pieri, Giuliana, and Lucia Rinaldi. "Italian Women Crime Writers." In Italian Crime Fiction. Ed. Giuliana Pieri. Cardiff: U of Wales P, 2011. 115-131.

Reddy, Maureen. Sisters in Crime: Feminism and the Crime Novel. New York: Continuum, 1988.

Simpson, Inga. "Torn between Two Genres: Sex and Romance in Lesbian Detective Fiction." CLUES. A Journal of Detection 27.2 (2009): 9-20.

Viazmenski, J. A. "Cinema as Negotiation in Rossana Campo's L'attore americano." Italica 78 (2001): 203-217.

Wilson, Anna. "Death and the Mainstream: Lesbian Detective Fiction and the Killing of the Coming-Out Story." Feminist Studies 22.2 (1996): 251-278.

Wilson, Rita. "On the Margins: Antonio Tabucchi's Investigative Reflections." In Differences, Deceits and Desires: Murder and Mayhem in Italian Crime Fiction. Ed. Mirna Cicioni and Nicoletta Di Ciolla. Newark: U of Delaware P, 2008. 13-25. 